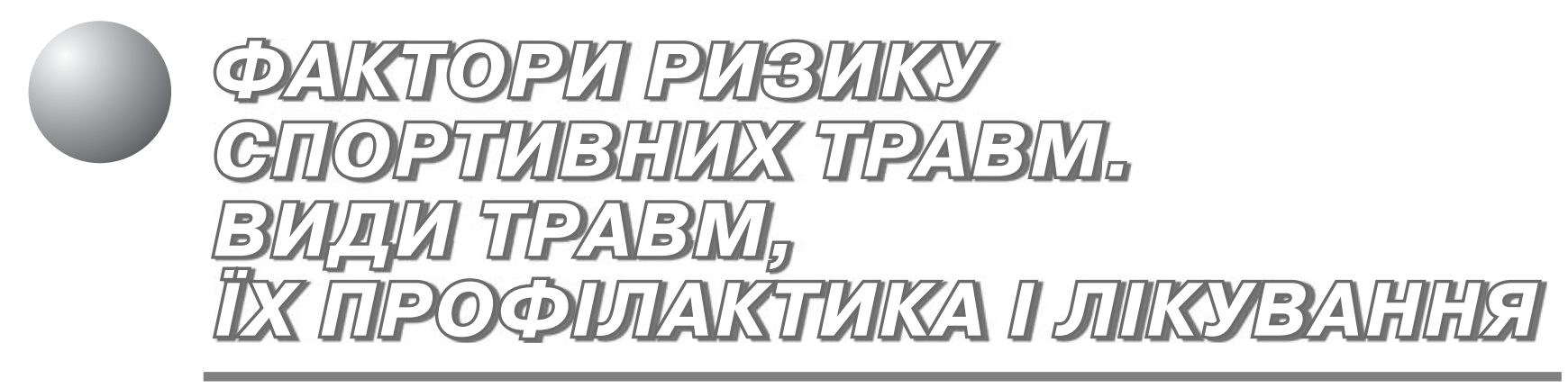

\title{
Вплив екстракорпоральної ударно- хвильової терапії на сухожилкову тканину (експериментальне дослідження)
}

\author{
В. М. Левенець ${ }^{1}$, М. Б. Циганок', \\ О. В. Сергієнко ${ }^{2}$ Б. І. Паламарчук \\ ${ }^{1}$ Центр спортивної травматології НУФВСУ, Київ, Україна \\ ${ }^{2}$ Інститут фармакології та токсикології АМН України, Київ, Україна \\ ${ }^{3}$ Інститут електрозварювання ім. О. Є. Патона НАН України, Київ, Україна
}

\begin{abstract}
Резюме. Проведены экспериментальные исследования и изучены изменения структуры сухожилий (пяточных) под влиянием экстракорпоральной сфокусированной и радиальной ударно-волновой терапии. Определены дегенеративные изменения и повреждения сосудистой системы под воздействием радиальных волн.
\end{abstract}

Ключевые слова: ударно-волновая терапия, сухожилие, дегенерация, сосуды.

Summary. An experimental study about changes in the structure of tendons (heel) caused by extracorporal focus and radial shock wave therapy were carried out. Defined degenerative changes and damage to the vascular system under the influence of radial waves.

Key words: shock wave therapy, tendon, degeneration, vessel.

Постановка проблеми. За останні роки значно поширилося використання ударних хвиль у багатьох видах клінічної терапії, у тому числі травматології й ортопедії $[1,6,8]$. Крім успішного використання екстракорпоральних, а також радіальних ударних хвиль оприлюднено інформацію про негативний вплив, а саме про пошкодження тканин, передусім судин.

Слід відмітити, що сьогодні окремі автори виявили інтерес до вивчення поширення ударних хвиль в неоднорідних середовищах для медичного застосування, а також до розробки терапевтичних приладів терапії за допомогою ударних хвиль і запровадження терапії ударними хвилями $[4,7,10]$.

Центр спортивної травматології Національного університету фрізичного виховання і спорту України займається питаннями використання ударних хвиль 32001 р. Екстракорпоральна ударно-хвильова терапія (ЕУХT) застосована більш як у 1000 спортсменів різних спеціалізацій
3 різними захворюваннями і наслідками травм опорно-рухової системи $[1,2,15]$.

Відомо, що високі результати в спорті, як правило, пов'язані зі значними фрізичними навантаженнями, які за певних умов виявляються позамежними і можуть призводити до розвитку синдрому перевантаження, а далі - до дегенеративно-дистрофрічних процесів з непереборним перебігом [2].

Спортсмени схильні до підвищеного травматизму і різних передпатологічних, патологічних станів, котрі не тільки знижують ефективність їх тренувальної і змагальної діяльності, а і становлять небезпеку для здоров'я.

3 втіленням у практику травматолога і спортивного лікаря ЕУХТ та радіальної ударно-хвильової терапії (РУХT) відкрилися не тільки можливості конкурувати з фрізичними методами, а також медикаментозними, такими, як нестероїдні протизапальні препарати, гормональні препарати і навіть оперативними методами лікування, 
а й певні переваги за рахунок покращення віддалених результатів і уникнення ускладнень і побічних явищ $[3,8,9,12]$.

В 1987 р. ЕУХТ вперше була використана для лікування в травматології та ортопедії під час ревізійного ендопротезування кульшового суглоба, а пізніше при лікуванні псевдоартрозу, осифікуючого бурситу плечового суглоба та лікування болю при окремих ентезопатіях $[4,6,9,10,12$, 14].

Єдиної схеми лікування або рекомендацій, що базувались би на дослідженнях, до сьогодні немає, окремі положення залишаються неоднозначними, спірними, а інколи суперечливими, і все ж, незважаючи на це, за даними німецьких авторів, до 2006 р. число пацієнтів, яким застосовувались ударні хвилі, перевищило мільйон осіб.

Останнім часом з'явились повідомлення про негативний вплив ударно-хвильової терапії на тканини людини. Так, у роботах К. Takayama, T. Saito [13] опубліковано дані про вплив ударних хвиль на окремі тканини. Передусім висвітлено результати ушкодження судинної системи. Ці автори вважають, що побічні ефекти є наслідком впливу ударної хвилі на тканини, можливо, за рахунок еоректу кавітації $[13,14]$.

Визначення негативного клінічного впливу окремими авторами не може не звернути уваги на подальші розробки окремих питань ударнохвильової терапії, тим більше, що є різні за характером ударні хвилі, а останніми роками - й апарати, які їх створюють.

Сьогодні крім «стандартних» питань до застосування ударних хвиль актуальними визначились індивідуальні питання щодо показань до використання сорокусованих і радіальних ударних хвиль при окремих захворюваннях опорнорухової системи взагалі і у спортсменів зокрема.

На жаль, поки ще не зовсім з'ясовані дані порівняльного аналізу впливу на організм радіальних та сфокусованих ударних хвиль. Що стосується впливу хвиль на сухожилки, наприклад, п'ятковий (ахіловий), то подібних робіт взагалі не було виконано.

У зв'язку з цим виникає декілька актуальних питань: які показання існують для застосування різних видів ударних хвиль і, особливо, у зв'язку 3 різними захворюваннями, які найбільш ефективні та безпечні апарати для різних ударних хвиль i, мабуть, найскладніше питання - що відбувається і які механізми впливу на тканини, які обробляються поверхнево чи глибоко. Крім того, важливим $€$ питання: яка різниця впливу сорокусованих і радіальних хвиль на тканини опорнорухової системи.
У Центрі спортивної травматології розроблено схему наукових досліджень, яка дозволила з'ясувати ряд спірних питань із проблеми ЕУХT та РУXT.

Мета дослідження - визначити морфологічні зміни нормального (здорового) п'яткового (ахілового) сухожилка під впливом радіальних (апарат MicroPulsor-MP1) та сорокусованих хвиль (п'єзоелектричний апарат PIESOWAN-100).

Матеріали і методи дослідження. Для виконання поставленої мети було проведено дослідження на 36 білих щурах у терміни 7, 30, 60 діб після проведення ЕУХТ та РУХТ з різною кількістю ударів за хвилину.

Методика ударних хвиль була такою: енерге-

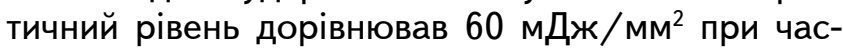
тоті 5 Гц з частотою ударів 1500 і проміжком між курсами 6 діб.

Всього було проведено 12 серій:

I серія - тварини через 7 діб після одноразового проведення РУХТ (пневматичний прилад 3 частотою 800 ударів за сеанс);

II серія - тварини через 7 діб після одноразового проведення сорокусованої ЕУХТ (п'єзоелектричний прилад з частотою 2000 ударів за сеанс);

III серія - тварини через 7 діб після одноразового проведення РУХТ (пневматичний прилад 3 частотою 400 ударів за сеанс);

IV серія - тварини через 7 діб після одноразового проведення сорокусованої ЕУХТ (п'єзоелектричний прилад з частотою 1000 ударів за сеанс);

V серія - тварини через 30 діб після 3-разового проведення РУХТ (пневматичний прилад 3 частотою 800 ударів за сеанс);

VI серія - тварини через 30 діб після 3-разового проведення сорокусованої ЕУХТ (п'єзоелектричний прилад з частотою 2000 ударів за сеанс);

VII серія - тварини через 30 діб після 3-разового проведення РУХТ (пневматичний прилад 3 частотою 400 ударів за сеанс);

VIII серія - тварини через 30 діб після 3-разового проведення сорокусованої ЕУХТ (п'єзоелектричний прилад з частотою 1000 ударів за сеанс);

IX серія - тварини через 60 діб після 3-разового проведення РУХТ (пневматичний прилад 3 частотою 800 ударів за сеанс);

$X$ серія - тварини через 60 діб після 3-разового проведення сорокусованої ЕУХТ (п'єзоелектричний прилад з частотою 2000 ударів за сеанс); 
XI серія - тварини через 60 діб після 3-разового проведення РУХТ (пневматичний прилад 3 частотою 400 ударів за сеанс);

XII серія - тварини через 60 діб після 3-разового проведення сфрокусованої ЕУХТ (п'єзоелектричний прилад з частотою 1000 ударів за сеанс).

Контролем слугував матеріал, взятий від інтактних тварин.

Призначені для гістологічного та гістохімічного дослідження тканини фріксували у $10 \%$ розчині нейтрального фрормаліну та рідині Карнуа, за стандартизованими методиками зневоднювали в етанолі зростаючої концентрації та заливали у парафрін. Гістологічні зрізи товщиною 3-5 мкм забарвлювали гематоксиліном та еозином, а також за методикою van Gieson. Глікозаміноглікани (ГАГ) виявляли забарвленням за методикою McManus, нуклеїнові кислоти - за методом Фельгена, фібрин - за методом PicroMalori. Препарати вивчали та фоотографували за допомогою мікроскопа Olimpus BX51.

Результати дослідження та їх обговорення. При розтині тварин експериментальних та контрольної груп істотних відмінностей структури внутрішніх органів та систем не відмічено. У місці проведення РУХТ з використанням пневматичного приладу навколо п'яткових сухожилків через 7 діб виявлялись набряк м'яких тканин, їх повнокров'я та петехіальні крововиливи, а через 30 і 60 діб сухожилки виглядали потовщеними, навколишні тканини були ущільнені на дотик, повнокровні. При застосуванні сфрокусованих хвиль п'єзоелектричного приладу навколо п'яткових сухожилків через 7, 30 і 60 діб макроскопічних ознак ушкодження, запалення та дисрегенераторних процесів не виявлено.

Проведені мікроскопічні дослідження продемонстрували наявність структурних та гістохімічних проявів дії РУХT, особливо при використанні пневматичного приладу, на п'яткові сухожилки та оточуючі їх тканини.

У контрольній групі тварин тканина п'яткового сухожилка має структуру щільної оформленої волокнистої сполучної тканини, утвореної однаково спрямованими пучками колагенових волокон, розмежованими рядами сплощених фріброцитів. До краю сухожилка щільно прилягають пучки м'язових волокон, що мають витягнуту форму. Цитоплазма їх гомогенна, слабо оксифрільна. Ядра витягнуті, еліпсоподібні, з рівномірно розподіленими уламками хроматину та декількома ядерцями, розташованими у центрі (рис. 1).

М'язові волокна розташовані дуже щільно, міжм'язовий простір вузький, щілиноподібний, 3 окремими клітинними елементами.

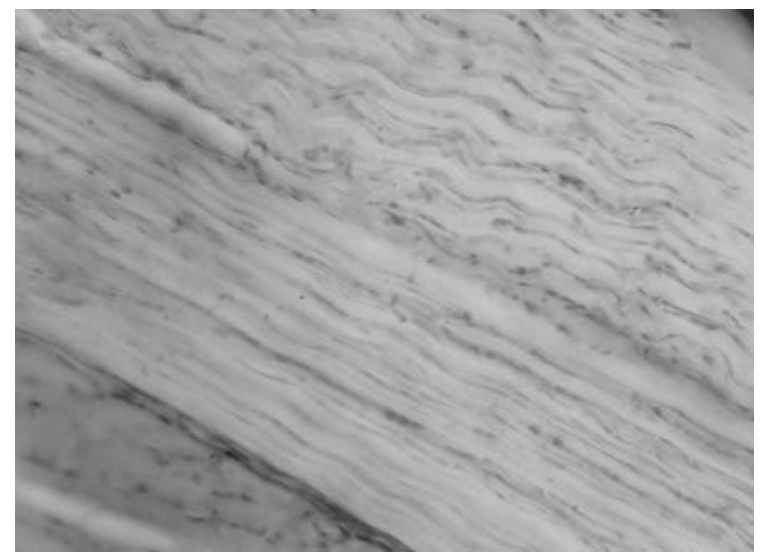

Рисунок 1 - Гістологічна структура п'яткового сухожилка інтактного щура. Забарвлення гематоксиліном та еозином. $\times 100$

Тканину сухожилка оточують також жирова тканина та глибокі шари шкіри, які не виявляють патологічних змін. Епідерміс представлений багатошаровим плоским ороговілим епітелієм звичайної структури. В глибині його виявляються клітини росткового шару призматичної форми. У цитоплазмі сплощених клітин зернистого шару містяться зернятка кератогіаліну. У дермі розрізнюються сосочковий та сітчастий шари. Цибулини волосся та залози шкіри мають звичайну структуру. Гіподерма представлена жировою клітковиною з окремими повнокровними судинами.

Гістохімічними методами дослідження в основній речовині сполучної тканини та м'язових волокнах виявляється значна кількість (ГАГ) (рис. 2), у ядрах фріброцитів та м'язових волокон - помірна кількість нуклеопротеїдів.

У тварин I та III груп на сьому добу експерименту виявлено ознаки альтернативного, дисциркуляторного та запального процесів, співвідношення яких дещо варіювало в окремих

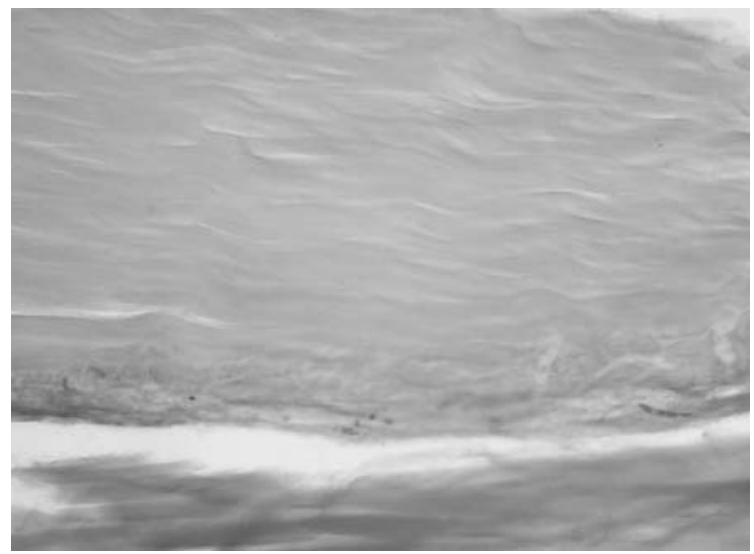

Рисунок 2 - Глікозаміноглікани у міжклітинній речовині п'яткового сухожилка та у прилеглих міоцитах інтактного щура. Забарвлення за методикою McManus [200]. ×100 
випадках. У досліджуваній тканині тварин при використанні радіальних хвиль спостерігається сполучення помірно виражених ознак альтерації строми з вираженими проявами порушень гемоциркуляції. Окремі пучки колагенових волокон сухожилка та сітчастого шару дерми помірно набряклі, розрихлені, у дермі, жировій та м'язовій тканинах виявляються розширення просвіту та повнокров'я судин, плазматичне просочення та склероз стінки окремих артерій, стази та тромби в їх просвіті, вогнищеві крововиливи (рис. 3).

У м'язовій тканині відмічаються перескорочення та фррагментації окремих волокон, поодинокі вогнища запальної інфрільтраціі.

Порушення гемоциркуляції та набряк тканини поєднується 3 вогнищевим накопиченням у ній ГАГ, деструкцією колагенових волокон переважно дерми.

Через 7 діб після РУХТ з використанням пневматичного приладу спостерігається велика кількість тканинних базофрілів у сполучній тканині, а також вогнища накопичення ГАГ та нуклеїнових кислот, що свідчить про наявність запального процесу (рис. 4).

Водночас у тварин II та IV груп через 7 діб після сорокусованої ЕУХT з використанням п'єзоелектричного приладу не виявлено ознак ушкодження п'яткового сухожилка й оточуючих тканин. У досліджуваних тканинах превалюють процеси переважно продуктивного характеру. На тлі помірного повнокров'я судин без ознак ушкодження їх стінки та тромбозу спостерігається збільшення кількості клітин, що розділяють пучки колагенових волокон у сухожилку, частина з них набуває вигляду фрібробластів.

Виражене накопичення нуклеїнових кислот (рис. 5) та ГАГ у клітинах сполучної тканини дерми, окремих міозитах та фрібробластах п'яткового сухожилка вказує на підвищену інтенсивність біосинтетичних процесів.

Наприкінці 30-ї доби після РУХT з використанням пневматичного приладу у більшості дослідних тварин V та VII груп тканину п'яткового сухожилка оточують розростання молодої грануляційної тканини (рис. 6) з численними тонкостінними судинами, вистеленими ендотеліоцитами 3 великими базофрільними округлими ядрами, фрібробластами та новоутвореними колагеновими волокнами. В окремих випадках у тканинах зберігаються ознаки порушень гемоциркуляції у вигляді тромбозу судин.

Наприкінці 30-ї доби ступінь зрілості грануляційної тканини варіює від ділянок з великою кількістю лімфроцитів, наявністю фрібробластів до вогнищ зрілої сполучної тканини, переважно у гіподермі, з фріброцитами та ущільненою

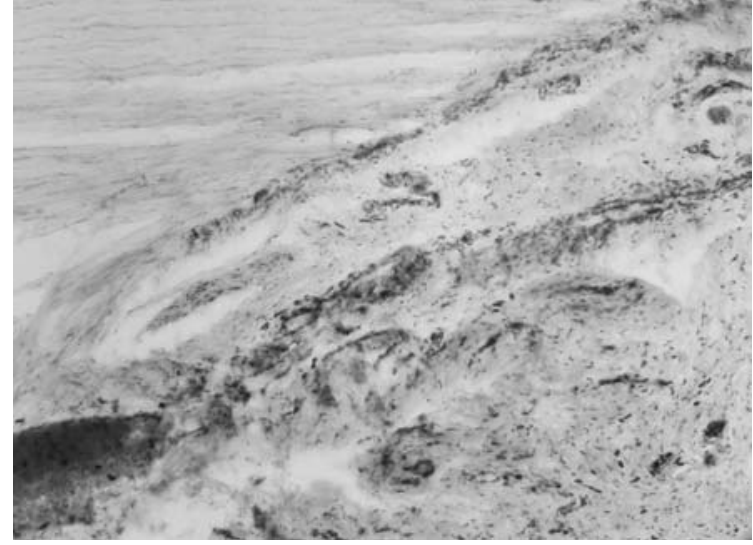

Рисунок 3 - Вогнищевий набряк сітчастого шару дерми та сухожилка, ушкодження стінки судин, тромбоз, крововилив через 7 діб після РУХТ з використанням пневматичного приладу з частотою 800 ударів. Забарвлення гематоксиліном та еозином. $\times 100$

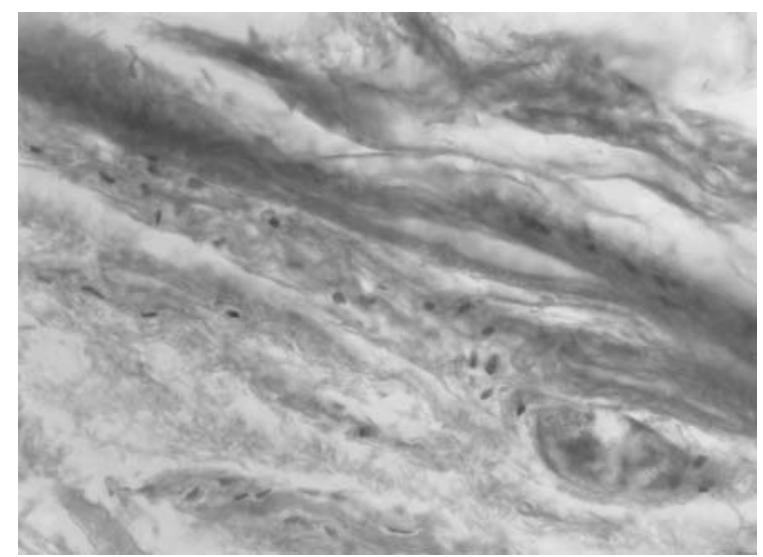

Рисунок 4 - Високий вміст глікозаміногліканів в клітинах сполучної тканини та пучках колагенових волокон через 7 діб після РУХТ з використанням пневматичного приладу. Забарвлення за методикою McManus. $\times 200$

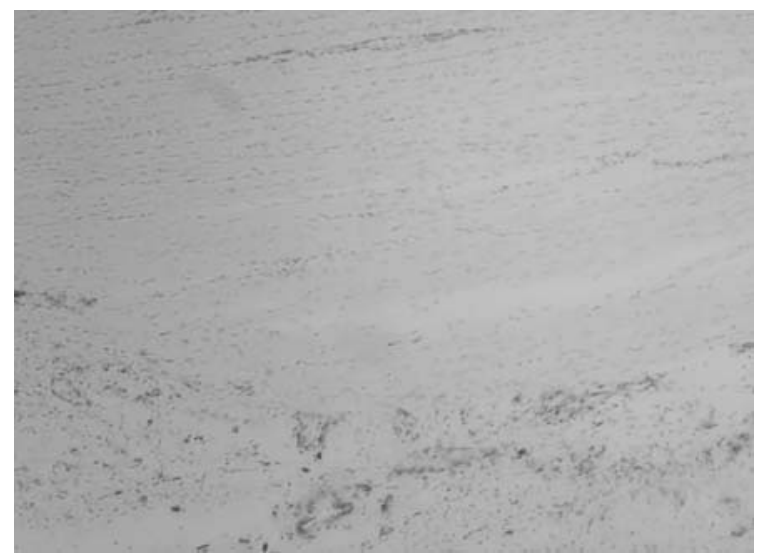

Рисунок 5 - Накопичення нуклеїнових кислот у клітинах сполучної тканини дерми та фрібробластах через 7 діб після ЕУХТ з використанням п'єзоелектричного приладу. Забарвлення за методом van Gieson. ×200 


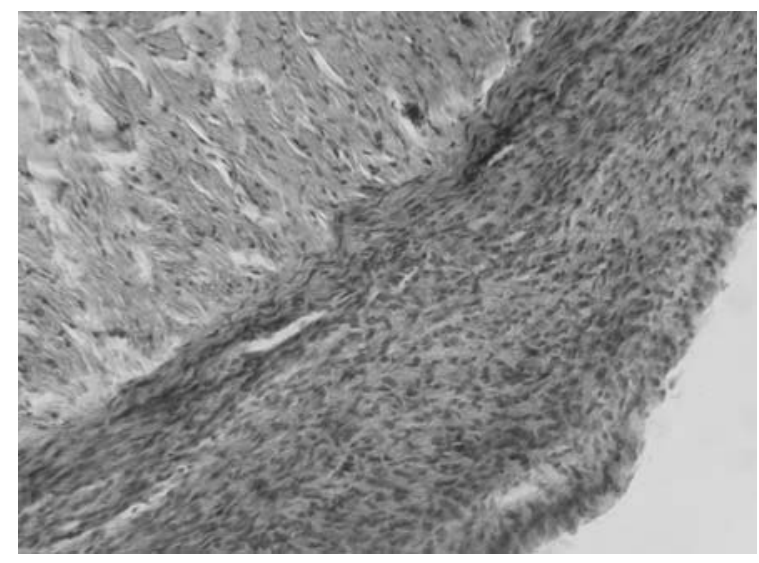

Рисунок 6 - Розростання молодої сполучної тканини через 30 діб після РУХТ з використанням пневматичного приладу з частотою 400 ударів. Забарвлення гематоксиліном та еозином. $\times 100$

сіткою хаотично направлених колагенових волокон, місцями гомогенізованих.

На рисунку 7 відмічено набряк колагенових волокон сухожилків і вростання зрілої сполучної тканини в сухожилкові волокна.

За даними гістологічного та гістохімічного методів дослідження, через 30 діб після застосування сфокусованих хвиль за допомогою п'єзоелектричного приладу не відмічено побічних дій у тканинах п'яткового сухожилка, м'язах та шкірі тварин.

По закінченні 60 діб експерименту у тварин, яким проводилась РУХТ, визначено численну проліферацію клітин фібробластів у сухожилку, перимізії і ендомізії (рис. 7), відмічається вростання судин у гіподерму із склерозуванням стінок судин і розростанням зрілої сполучної тканини (рис. 8).

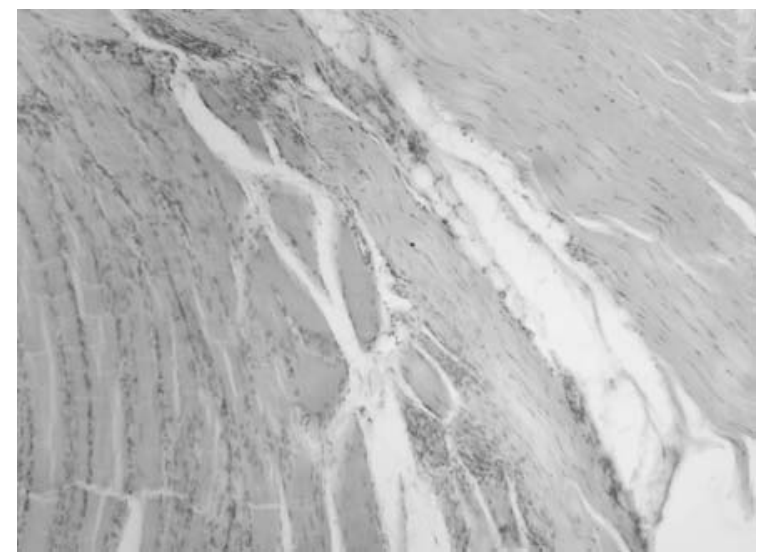

Рисунок 7 - Проліферація фрібробластів у перимізії, ендомізії та сухожилку, набряк колагенових волокон через 60 діб після РУХТ з використанням пневматичного приладу з частотою 400 ударів. Забарвлення гематоксиліном та еозином. $\times 100$

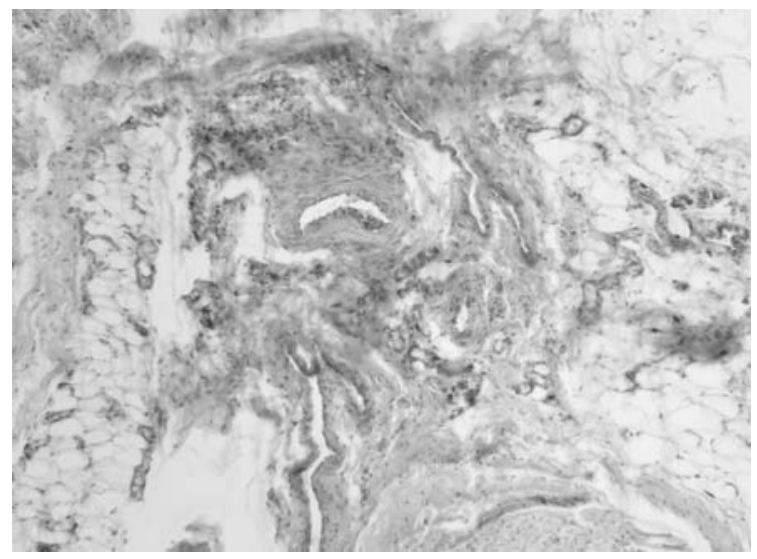

Рисунок 8 - Розростання зрілої сполучної тканини із склерозуванням стінок судин у гіподермі через 60 діб РУХT з використанням пневматичного приладу з частотою 400 ударів. Забарвлення за методом van Gieson ×100

Висновки. В результаті макроскопічних, гістологічних та гістохімічних методів досліджень п'яткових сухожилків встановлено, що вплив різних хвиль, зокрема радіальних та сфокусованих 3 допомогою відповідно пневматичного та п'єзоелектричного приладів, викликає неоднакові зміни.

Так, у короткі терміни, а саме 7 та 30 діб, сорокусовані п'єзоелектричним апаратом ударні хвилі не спричинили змін у п'ятковому сухожилку. Не відмічено також змін у м'язах та шкірі тварин.

Під впливом РУХТ (за допомогою пневматичного приладу) у тварин виявлено набряк сухожилків, крововиливи та тромбози судин, розростання молодої грануляційної тканини з численними тонкостінними судинами, що вислані ендотеліоцитами з великими колагеновими волокнами, котрі мають хаотичну направленість. Фібробласти містять у цитоплазмі значну кількість ГАГ та нуклеопротеїдів. Цей фракт підтверджує незначне накопичення у клітинах сполучної тканини нуклеїнових кислот.

Водночас слід відмітити, що побічні дії з боку судинної системи не носять системний і травмуючий характер і на 60 добу вони майже повністю зникають, тобто побічні дії, які відмічені протягом 30 діб, не впливають негативно на структуру і функцію сухожилків.

Таким чином, у результаті проведеного експериментального дослідження з'ясувалось деяке протиріччя: у короткі терміни (7-30 діб) побічні дії РУХТ виявились у судинних розладах - крововиливи та тромбоз судин, розростання грануляційної, а пізніше - молодої сполучної тканини. У більш пізні терміни (60 діб) зменшились судинні розлади, а сполучна тканина, зокрема зріла, має тенденцію до вростання у тканину сухожилка.

Ці явища поки що не мають пояснень, що свідчить про необхідність продовження дослідження. 


\section{Література}

1. ЛеВенець В. М. Синдром перевантаження діагностика і лікування / В. М. Левенець // Спорт. мед. 2003. - № 1. - С. 32-36.

2. ЛеВенець В. Екстракорпоральна ударно-хвильова терапія лікуванні ентезопатій у спортсменів / В. Левенець, М. Риган // Спорт. мед. - 2004. - № 1-2. - С. 90-93.

3. Dahmen G. P. Extracoiporale Stosswellentherapie (ESWA) zur Behanlunng Von knochennahen weichtellscmerzen. Indikation. Techik imd vorleufige Ergibnisse. In: Deutsche Geseleschafl fur stosswellen-lithotripsie (ed/): Konsensus Workshop der Deutschen Geseleschafl fur stosswellen-lithotripsie / G. P. Dahmen, V. C. Nam, L. Meiss // Tubingen: AtemptoVerlag. - 1993. - P. 143-148.

4. Furia J. P. High Energy Extracorporal Shok Wave Terepyas Treatment for Chronic Noninsertional Achilles Tendinopaty // J. P. Furia // J. Amer. Orthoped. Society for Sports Med. - 2009. - 9/5. - P. 78-83.

5. Haupt $G$. Use of exstracorporal Shock wave in the treatment of pseudaarthross, tendinopathy and other arthopedic diseases / G. Haupt // J. Urol. - 1997. - N I58. P. 4-11.

6. Heist J. Die ESWT der Epicondylopetthia radialis und ulharis. Eine neues Behand lungkonzert knochennahen Weichtellschmerzen / J. Heist, D. Steger // Orthoped Mitteilungen. - 1994. - N 3. - P. 173-175.

7. Hosseini S. H. R. Development of shock wave assisted therapeutic devices and establishment of shock wave therapy / S. Y. R. Hosseini, V. Menezes, S. Moosavi-Nejad et al. // Mininrately Jnvasive Therapies. - 2006. - 15. P. $230-240$.

8. Knobloch K. Superior Achilles tendon microcirculation in tendinopathy among symptomatic female vs. malt patients / K. Knobloch, L. Schreibmuller, R. Meller et al. // Am. J. Sports Med. - 2008 - 36 (3). - P. 509-514.

9. Lohrer L. RESWT - Schmerrtherapie in der Orthopadie, Sport medidzin I Enticlung and Einsats / H. Lohrer. J. Sehцll, S. Azents / / Herstellung und verlag: Books on Demand $\mathrm{GmbH}$, Nordlrfedt. - 2004. - kapitel 1. - P. 75-89.

10. Maffuilli N. Light microscopic histology of Achilles tendon ruptures. A. comparsion with unruptured tendos // N. Maffuilli, Y. Barras, S. W. Ewen // Am. J. Sport Med. 2000. - 28 (6). - P. 857-863.

11. Sorosky B. Practical management of Achilles Tendinopathy / B. Sorosky, J. Press, C. Plastaras et al. / / Clin. J. Sport Med. - 2004. - 14 (I). - P. 40-44.

12. Stergioulas $A$. Effects of low-level laser therapy and eccentric exercises in the treatment of recriacional athletes with chronic Achilles tendinopathy / A. Stergioulas, M. Stergioula, R. A. Lopes-Martins et al. // Am. J. Sports Med. 2008. - 13. - P. 468-473.

13. Takayama K. Schock wave therapy and medical applications / K. Takayama, T. Saito / / An. Rev. Fluid mech. 2004. - 36. - P. 347-379.

14. Wang $C$. J. Shock wave therapy induces neoxascularization at the tendon-bone function / C. J. Wang et al. / / J. Orthop. Res. - 2003. - 21. - P. 984-989.

15. Lewenets W., Rigan M. / Shock wave therapy in orthoprdic and sport meducine / Kiev: «Fenix». - 2012. P. 155.

\section{References}

1. Levenets V. M. Overload syndrome - diagnosis and treatment / V. M. Levenets // Sports Medicine. - 2003. N 1. - P. 32-36.

2. Levenets $V$. Extracorporeal shock wave therapy treatment entezopatiy athletes / V. Levenets, M. Regan / / Sports Medicine. - 2004. - N 1-2. - P. 90-93.

3. Dahmen G. P. Extracoiporale Stosswellentherapie (ESWA) zur Behanlunng Von knochennahen weichtellscmerzen. Indikation. Techik imd vorleufige Ergibnisse. In: Deutsche Geseleschafl fur stosswellen-lithotripsie (ed/): Konsensus Workshop der Deutschen Geseleschafl fur stosswellen-lithotripsie / G. P. Dahmen, V. C. Nam, L. Meiss // Tubingen: AtemptoVerlag. - 1993. - P. 143-148.

4. Furia J. P. High Energy Extracorporal Shok Wave Terepyas Treatment for Chronic Noninsertional Achilles Tendinopaty // J. P. Furia // J. Amer. Orthoped. Society for Sports Med. - 2009. - 9/5. - P. 78-83.

5. Haupt G. Use of exstracorporal Shock wave in the treatment of pseudaarthross, tendinopathy and other arthopedic diseases / G. Haupt // J. Urol. - 1997. - N I58. P. 4-11.

6. Heist J. Die ESWT der Epicondylopetthia radialis und ulharis. Eine neues Behand lungkonzert knochennahen Weichtellschmerzen / J. Heist, D. Steger // Orthoped Mitteilungen. - 1994. - N 3. - P. 173-175.

7. Hosseini S. H. R. Development of shock wave assisted therapeutic devices and establishment of shock wave therapy / S. Y. R. Hosseini, V. Menezes, S. Moosavi-Nejad et al. // Mininrately Jnvasive Therapies. - 2006. - 15. P. $230-240$.

8. Knobloch $K$. Superior Achilles tendon microcirculation in tendinopathy among symptomatic female vs. malt patients / K. Knobloch, L. Schreibmuller, R. Meller et al. // Am. J. Sports Med. - 2008 - 36 (3). - P. 509-514.

9. Lohrer L. RESWT - Schmerrtherapie in der Orthopadie, Sport medidzin I Enticlung and Einsats / H. Lohrer. J. Sehцll, S. Azents // Herstellung und verlag: Books on Demand $\mathrm{GmbH}$, Nordlrfedt. - 2004. - kapitel 1. - P. 75-89.

10. Maffuilli N. Light microscopic histology of Achilles tendon ruptures. A. comparsion with unruptured tendos // N. Maffuilli, Y. Barras, S. W. Ewen // Am. J Sport Med. 2000. - 28 (6). - P. 857-863.

11. Sorosky B. Practical management of Achilles Tendinopathy / B. Sorosky, J. Press, C. Plastaras et al. / / Clin. J. Sport Med. - 2004. - 14 (I). - P. 40-44.

12. Stergioulas $A$. Effects of low-level laser therapy and eccentric exercises in the treatment of recriacional athletes with chronic Achilles tendinopathy / A. Stergioulas, M. Stergioula, R. A. Lopes-Martins et al. // Am. J. Sports Med. 2008. - 13. - P. 468-473.

13. Takayama K. Schock wave therapy and medical applications / K. Takayama, T. Saito // An. Rev. Fluid mech. 2004. - 36. - P. 347-379.

14. Wang $C$. J. Shock wave therapy induces neoxascularization at the tendon-bone function / C. J. Wang et al. // J. Orthop. Res. - 2003. - 21. - P. 984-989.

15. Lewenets W., Rigan M. / Shock wave therapy in orthoprdic and sport meducine / Kiev: «Fenix». - 2012. P. 155. 